\title{
Evaluation of The Physical Properties of Hazelnut Shell Dust-Added Brake Pad Samples Treated With Cryogenic Process
}

\author{
Araştırma Makalesi / Research Article \\ Gülşah AKINCIOĞLU ${ }^{1}$, Sıtkı AKINCIOĞLU ${ }^{2}$, Hasan ÖKTEM ${ }^{3}$, İlyas UYGUR ${ }^{4}$ \\ 1* Gümüşova Vocational School, Department of Machine and Metal Technologies, Duzce University, Duzce, Turkey \\ ${ }^{2}$ Gümüşova Vocational School, Department of Machine and Metal Technologies, Duzce University, Duzce, Turkey \\ ${ }^{3}$ Hereke Vocational School, Department of Machine and Metal Technologies, Kocaeli University, Kocaeli, Turkey \\ ${ }^{4}$ Engineering Faculty, Department of Mechanical Engineering, Duzce University, Duzce, Turkey
}

(Received : 08.03.2018; Accepted : 14.05.2018)

\begin{abstract}
After understanding that asbestos fibers are harmful to human health; researchers have investigated for alternative and eco-friendly materials. Agricultural products can be an example of these alternative and environmentally friendly materials because they are easily supplied. Thus, in this study, asbestos-free automotive brake pads produced from $\% 7$ hazelnut dusts with other seventeen additives. Hazelnut shell is preferred because it is widespread in our country. Cryogenic process applied at $-80^{\circ} \mathrm{C}$ to the brake pads. Before and after cryogenic treatment, the produced brake pads properties such as water absorption, hardness test, porosity and microstructural examinations were investigated. The hardness values of brake pads increases after cryogenic and cyclic-cryogenic process. The highest values obtained for the B-CYC sample.
\end{abstract}

Keywords: Brake pads, hazelnut shell dust, cryogenic treatment, hardness.

\section{INTRODUCTION}

Brake pads are one of important parts of braking system for all types of vehicles that are equipped with disc brake. Brake pads are steel backing plates with friction material bound to the surface facing the brake disc [1]. Friction materials used in automotive brake linings are commonly composed of more than 10 components $[2,3]$. Recent decades put emphasis on new requirements connected with newly developed engineering materials focused on their eco-friendliness. This eco-friendly tendency has found its way to the friction composites industry as well [4] . Because of the brake pads commonly used as friction composites in the automotive industry, eco-friendliness has increased the importance. Researchers have begun to experiment with natural additives such as hazelnut, walnut, boron etc. Amaren et al. used periwinkles shells for the brake pads. Their researches indicate that periwinkle shell particle can be used effectively as a replacement for asbestos in brake pad production[5]. Idris et al. worked non-asbestos brake pad with banana peels. They use banana peels to replaced asbestos and resin as a binder. They found that the brake pads can be produced with additive banana peels particles [6]. Bahari et al. investigated the effects of the rice husk dust in the brake pads [7]. They dried and milled the rice husk to powder and then they produced brake pads examples. They compare the hardness of samples with that of the commercial brake pads. The presence of rice husk as an organic filler has only affected the good hardness properties in the brake pad formulation. Ikbambese et al. [8] in their study produced asbestos-free automotive brake pads from palm kernel fibers and they evaluated

*Sorumlu Yazar (Corresponding Author)

e-posta : gulsahakincioglu@gmail.com the effects of the palm kernels as the binder. The results show that palm kernel fiber can be suitable replacement to asbestos for brake pad production. Sisal fiber is a kind of plant fiber with cellulose structure. Xin et al. [9] used it for the first time as a reinforce resin and compare with the commercial brake pads. They found that sisal fiber has the potential to be an ideal substitute fiber of asbestos for brake composites. Ma et al. used Bamboo fibers in their paper as the reinforced resin and they found that bamboo fiber has the positive effects on the friction performance of the brake pads [10]. Matejka et al. research the effects of the jute fibers and powderized hazelnut shells as natural fillers in non-asbestos organic non-metallic friction composites. They prepared two groups of samples: the first group contains jute fibers and graphite; the second one contains jute fiber and hazelnut shells. The samples with hazelnut and jute fibers showed the acceptable stability of friction coefficient [11]. Dadkar et al., Mohanty et al. evaluated that fly ash-filled, and aramid fiber reinforced hybrid polymer matrix composites (PMC) for friction braking applications. They have successfully incorporated fly ash into phenolic matrix and fabricated the composites with a small amount of aramid fibers to enhance the perform strength. In addition, the researchers said that stable friction coefficient has been obtained in the composite by using highest flyash dust $[12,13]$. Fu et al. [14] developed in their study eco-friendly brake friction composites containing flax fibers. They found that the role of flax fibers in the composites is to stabilize the friction coefficient and to improve the wear rate at high temperature.

In this study, hazelnut shell dusts were studied which is widely produced in Turkey. Brake pads were produced 
with hazelnut shell and other dusts. The produced brake pads were compared with the original commercial brake pads. The brake pads were subject to cryogenic treatment at $-80^{\circ} \mathrm{C}$ in $24 \mathrm{~h}$ and $6 \mathrm{~h}$ cryogenic treatment, $6 \mathrm{~h}$ room temperature holding and again $6 \mathrm{~h}$ cryogenic treatment for 4 times called cyclic-cryogenic treatment. The effects of these treatments on the hardness, water soaking, the weight change and microstructural examinations of the brake pads were investigated.

\section{EXPERIMENTAL PROCEDURE}

\subsection{Materials/equipment}

In addition to hazelnut shell powder, 17 different powder materials were used in the production of the brake pads. The hazelnut shell dust is shown in Figure 1. The brake pads were manufactured using the hot-pressing method. A Shore D type device was used for hardness measurement. Water and oil absorption ratios were measured with precision scales. The surface images of the brake pads were examined with an optical microscope.

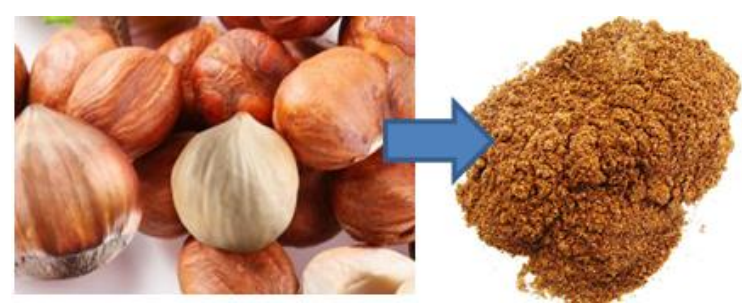

Figure 1. Hazelnut shell dust

\subsection{Method}

In this study, 17 common dusts and hazelnut dust were used to produce the organic brake pad samples. Hazelnut shells were milled to form the dust for the production of the brake pads. The sieved size of the hazelnut dust was $250-400 \mu \mathrm{m}$. This dust was homogeneously mixed with the other ingredients (Table 1) using a mechanical mixer for a period of $20 \mathrm{~min}$. The friction material and the mixer are shown in Figures 2.
Table 1. Common brake pad compositions

\begin{tabular}{|c|c|c|c|}
\hline No. & $\begin{array}{l}\text { Friction } \\
\text { Materials }\end{array}$ & $\begin{array}{l}\text { Compositi } \\
\text { on } \\
\text { (wt. \%) }\end{array}$ & $\begin{array}{l}\text { Grain Size } \\
\qquad(\mu \mathrm{m})\end{array}$ \\
\hline 1 & Steel fiber & $15-20$ & 125 \\
\hline 2 & Rock wool & $3-6$ & $6-10$ \\
\hline 3 & Kevlar pulp & $0.5-2$ & 12 \\
\hline 4 & Graphite & $5-7$ & 45 \\
\hline 5 & Phenolic resin & $6-8$ & 63 \\
\hline 6 & Vermiculite & $6-8$ & 500 \\
\hline 7 & Brass & $4-6$ & $50-100$ \\
\hline 8 & Calcium hydroxide & $7-9$ & 40 \\
\hline 9 & Zirconium Silicate & $3-5$ & 10 \\
\hline 10 & Metal sulfide & $0.5-1$ & 45 \\
\hline 11 & Iron oxide $\left(\mathrm{Fe}_{2} \mathrm{O}_{3}\right)$ & $1-3$ & 0.2 \\
\hline 12 & Rubber scrap & $4-6$ & 50 \\
\hline 13 & Baryte & $6-8$ & 55 \\
\hline 14 & Rubber (NBR) & $2-4$ & 50 \\
\hline 15 & Petrocoke & $3-5$ & 125 \\
\hline 16 & $\begin{array}{l}\text { Chalcopyrite } \\
\left(\mathrm{CuFeS}_{2}\right)\end{array}$ & $4-7$ & 50 \\
\hline 17 & Mica+silica & $4-5$ & $50-100$ \\
\hline 18 & Hazelnut shell dust & 7 & $250-400$ \\
\hline
\end{tabular}

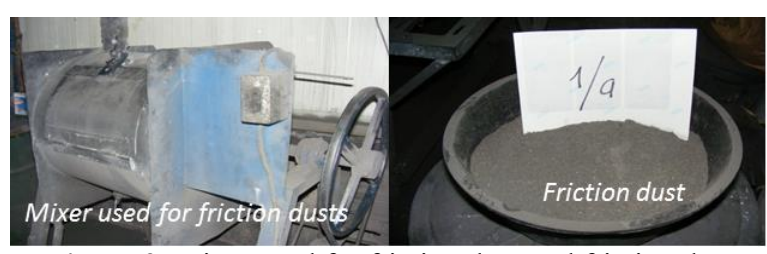

Figure 2. Mixer used for friction duzt and friction dust

The production of the brake pads consisted of a series of unit operations including mixing, cold- and hot-pressing, cooling, post-curing and finishing. The brake pad mixtures prepared in the appropriate proportions were hot-pressed in metal molds at a temperature of $180 \pm 5^{\circ} \mathrm{C}$ and pressure of $9.806 \mathrm{~N} / \mathrm{mm}^{2}$ for $6 \mathrm{~min}$. After the pressing process, the brake pads were unmolded and held in an electric furnace with circulating air at temperatures of $300-150^{\circ} \mathrm{C}$ for $10 \mathrm{~h}$. After post-curing, the brake pads were finished using a polisher-grinder with various sizes of grinding paper to obtain the final products. The

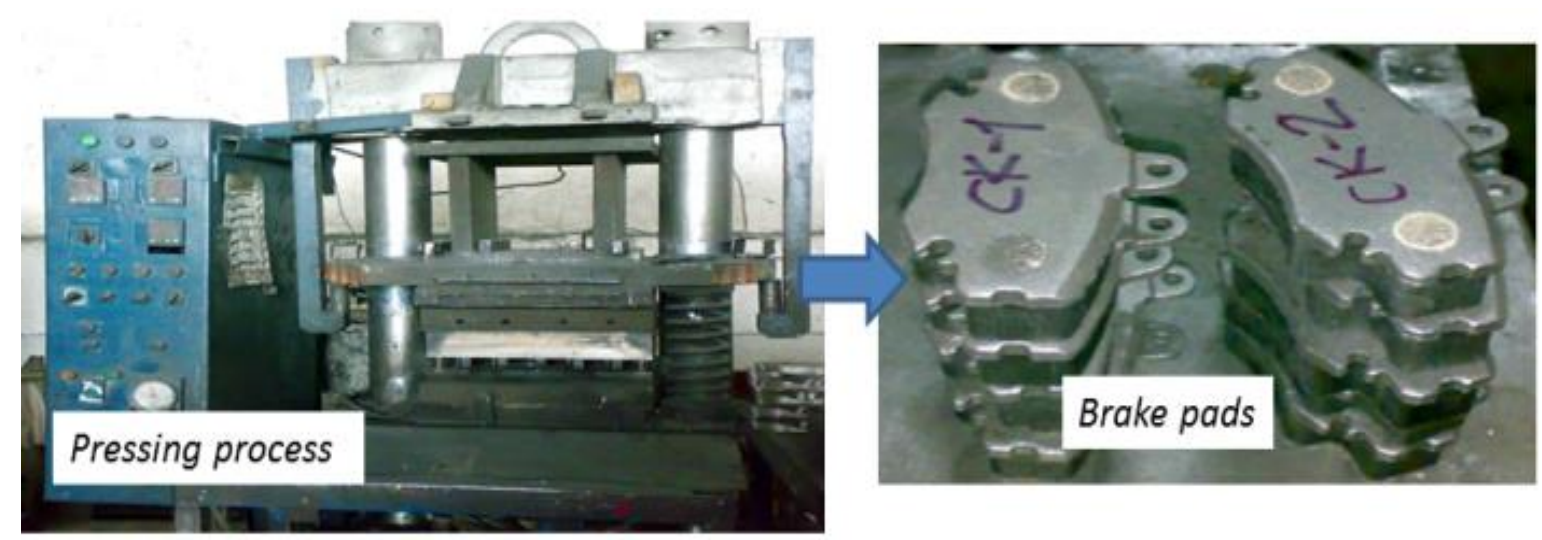

Figure 3. Pressing process and produced brake pads 
volume of the mixture before hot-pressing (weight $=120$ $\mathrm{g}$; thickness $=48 \mathrm{~mm}$ ) was three times less after the procedure (thickness $=16 \mathrm{~mm}$ ). The production of the brake pads is shown in Figure 3. The brake pads were separated into two main groups: brake pads with hazelnut Table 2. Codes for the brake pad treatments shell dust and commercial brake pads. The codes assigned to the brake pads are given in Table 2 .

\begin{tabular}{|c|c|c|}
\hline Description & Code & Treatment \\
\hline \multirow{6}{*}{ 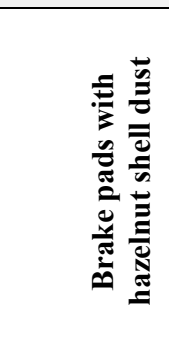 } & B & Brake pads with hazelnut dust \\
\hline & B-W & Brake nad with hazelnut dust soaked in water $24 \mathrm{~h}$ \\
\hline & $\mathrm{B}-\mathrm{C}$ & Brake pad with hazelnut dust, cryogenic treatment $24 \mathrm{~h}$ \\
\hline & B-C-W & Brake pad with hazelnut dust, cryogenic treatment $24 \mathrm{~h}$, soaked in water $24 \mathrm{~h}$ \\
\hline & $\mathrm{B}-\mathrm{CYC}$ & Brake pad with hazelnut dust, cyclic-cryogenic treatment $6 \mathrm{~h} \times 4$ \\
\hline & $\mathrm{B}-\mathrm{CYC}-\mathrm{W}$ & $\begin{array}{l}\text { Brake pad with hazelnut dust, cyclic-cryogenic treatment } 6 \mathrm{~h} \times 4 \text {, soaked in } \\
\text { water } 24 \mathrm{~h}\end{array}$ \\
\hline \multirow{2}{*}{ 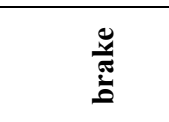 } & $\mathrm{C}$ & Commercial brake pads \\
\hline & $\mathrm{C}-\mathrm{W}$ & Commercial brake pad, soaked in water $24 \mathrm{~h}$ \\
\hline \multirow{4}{*}{ 苞 } & $\mathrm{C}-\mathrm{C}$ & Commercial brake pad, cryogenic treatment $24 \mathrm{~h}$ \\
\hline & $\mathrm{C}-\mathrm{C}-\mathrm{W}$ & Commercial brake pad, cryogenic treatment $24 \mathrm{~h}$, soaked in water $24 \mathrm{~h}$ \\
\hline & $\mathrm{C}-\mathrm{CYC}$ & Commercial brake pad, cyclic-cryogenic treatment $6 \mathrm{~h} \times 4$ \\
\hline & C-CYC-W & Commercial brake pad, cyclic-cryogenic treatment $6 \mathrm{~h} \times 4$, soaked in water $24 \mathrm{~h}$ \\
\hline
\end{tabular}

The weight, hardness and thickness of all samples were measured before and after the processes, as shown in Figure 4.

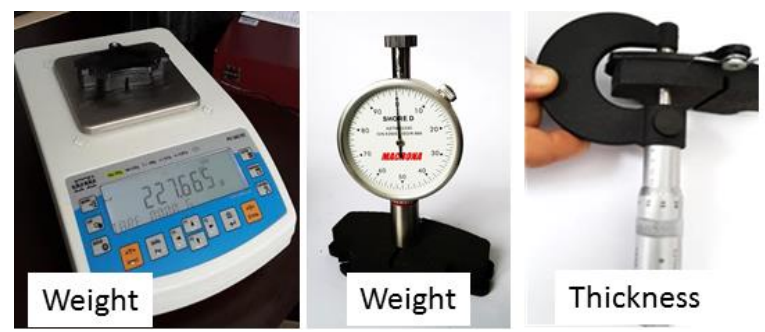

Figure 4. Measurement of the brake pads

Samples B-W and C-W were immersed in water, as shown in Figure 5. The B and $\mathrm{C}$ brake pads were both subjected to cryogenic treatments at $-80{ }^{\circ} \mathrm{C}$ for $24 \mathrm{~h}$ and to cyclic-cryogenic treatment for $6 \mathrm{~h} \times 4$, as shown in Figure 5.

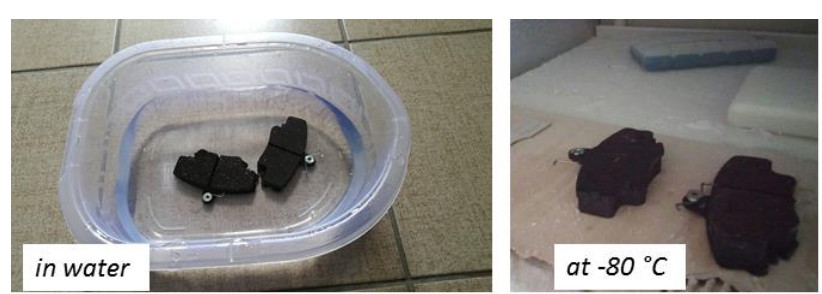

Figure 5. Brake pad samples $B-W$ and $C-W$ in water and Brake pads at $-80^{\circ} \mathrm{C}$

The cyclic-cryogenic process was applied to the B-CYC and C-CYC brake pad samples. They were held at $-80{ }^{\circ} \mathrm{C}$ for $6 \mathrm{~h}$ and then kept at room temperatures for $18 \mathrm{~h}$. This operation was repeated over four days. After the cryogenic treatments, the brake pads were immersed in water for $24 \mathrm{~h}$.

\section{RESULTS AND DISCUSSION}

\subsection{Microstructural evaluation of brake pads}

The brake pads developed in this study were composed of fillers, binders, reinforcement material, friction modifiers and abrasives. The matrix of the brake pads included rock wool, vermiculite, rubber scrap, baryte, calcium hydroxide, mica, phenolic resin and rubber. It can be seen in Figure 6 that the friction dust was distributed homogeneously within the matrix of the brake pads. The gray regions are the matrix (fillers and binders), the bright, needle-like portions are 
reinforcement (steel fiber) and the remaining material consists of friction modifiers and abrasives.

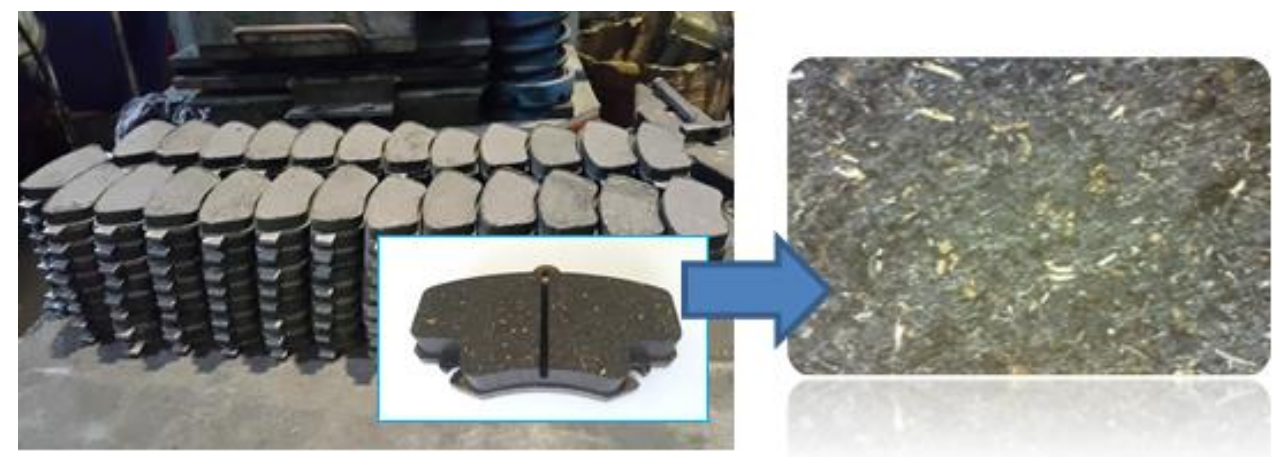

Figure 6. Distribution of friction dust in the brake pads

Microstructure images of the brake pad samples No porosity or obvious defects were observed in any of produced with hazelnut shell and the commercial pads the samples. However, more coarse hazelnut dust can be after soaking in water are shown in Figures 7 and 8. In seen these pictures.

both figures, similar microstructural features can be seen.
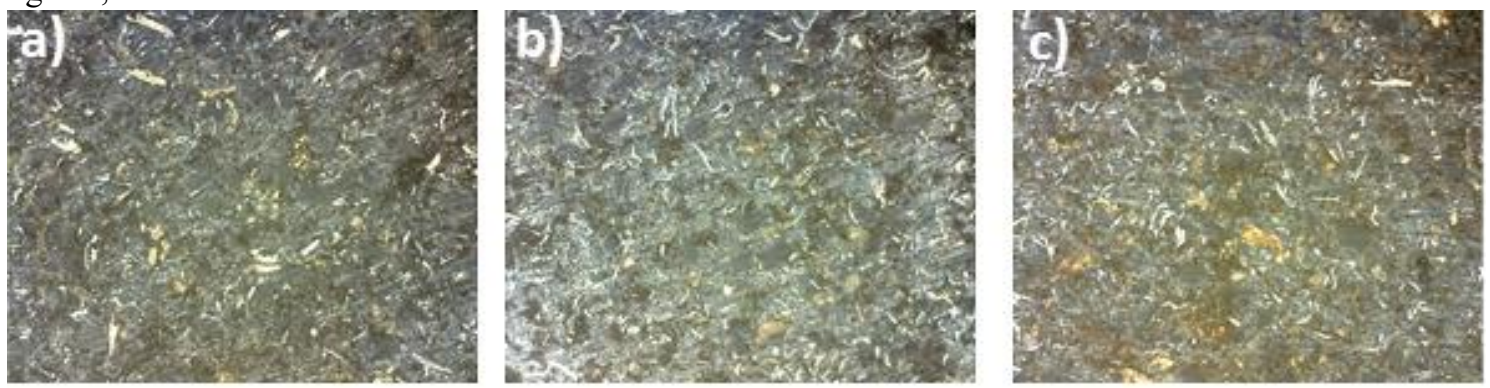

Figure 7. Microstructure of hazelnut dust brake pads: (a) B-W, (b) B-C-W, (c) B-CYC-W
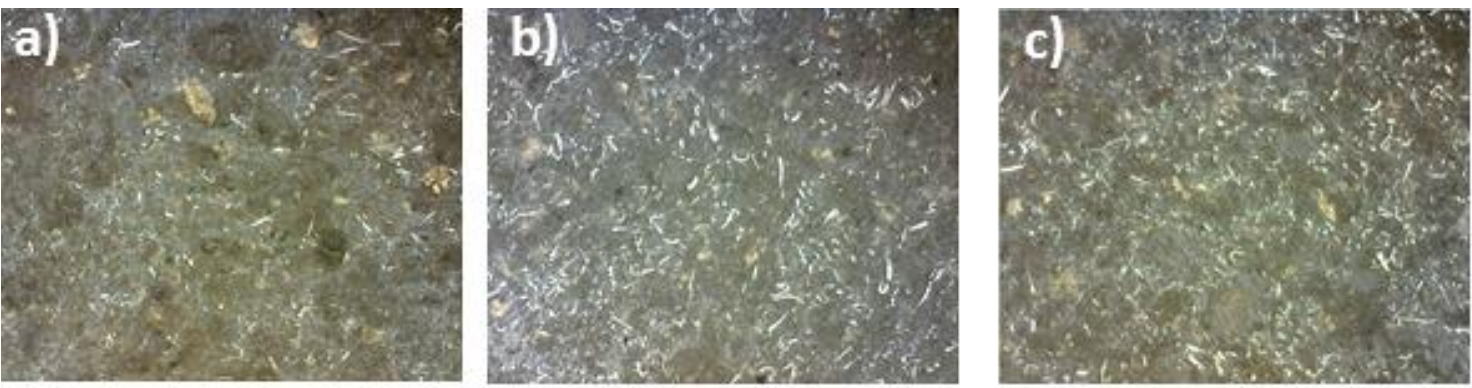

Figure 8. Microstructure of commercial brake pads: (a) C-W, (b) C-C-W, (c) C-CYC-W

\subsection{Hardness measurement and dimensional changes}

The hardness values and weight changes of the brake pads are shown in Table 3. The table suggests that both sample values are almost identical. In all cases, the hardness values were slightly decreased after immersion in water at room temperature for $24 \mathrm{~h}$. However, cryogenic treatment resulted in an increase in the hardness values for both samples. Moreover, a further slight increase in hardness values can be seen with the cyclic-cryogenic treatment. A similar trend was also observed in the weight changes of the samples. The weight gain for B-W was $7 \mathrm{mg}$. After the single $24 \mathrm{~h}$ cryogenic treatment, the weight gain decreased to $3 \mathrm{mg}$ and to $1 \mathrm{mg}$ after the cyclic-cryogenic treatment. The trend was nearly the same for the commercial reference pads as well. It is clear that both single cryogenic and cyclic-cryogenic treatment slightly improved the hardness values and enabled less water absorption. In the study of Akincioglu et al.[15], brake pads produced with $3.5 \%$ added hazelnut dust were immersed in water and oil for $24 \mathrm{~h}$. They reported that the samples with hazelnut dust had absorbed more water than the commercial brake pads. 
Table 3. Hardness values and weight change in tested brake pads

\begin{tabular}{ccc}
\hline Material Code & $\begin{array}{c}\text { Hardness (Shore } \\
\text { D) }\end{array}$ & $\begin{array}{c}\text { Weight Gain } \\
\text { (mg) }\end{array}$ \\
\hline B & 88 & 240 \\
B-W & 87 & 7 \\
B-C & 90 & 0 \\
B-C-W & 88 & 3 \\
B-CYC & 91 & 0 \\
B-CYC-W & 90 & 1 \\
C & 88 & 238 \\
C-W & 87 & 4 \\
C-C & 89 & 0 \\
C-C-W & 88 & 4 \\
C-CYC & 90 & 0 \\
C-CYC-W & 90 & 1 \\
\hline
\end{tabular}

The dimensions of the brake pads with hazelnut dust and the commercial pads were determined using a digital caliper before and after the water absorption test. The dimensional changes of the brake pads are listed in Table 4. The biggest change in width in all of the brake pads was observed in the hazelnut-reinforced samples. The higher porosity rate of the wood-based hazelnut dust may have been the reason they absorbed more water compared to the commercial pads.

Table 4. Dimensional changes of the brake pads

\begin{tabular}{|c|c|c|c|}
\hline Description & Design & Length (mm) & Width (mm) \\
\hline \multirow{5}{*}{ 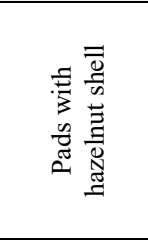 } & B & 92.72 & 17.35 \\
\hline & B-W & +0.17 & +0.21 \\
\hline & B-C & +0.01 & +0.01 \\
\hline & B-C-W & +0.11 & +0.1 \\
\hline & $\begin{array}{l}\text { B-CYC } \\
\text { B-CYC-W }\end{array}$ & $\begin{array}{l}0 \\
+0.07\end{array}$ & $\begin{array}{l}0 \\
+0.09\end{array}$ \\
\hline \multirow{6}{*}{ 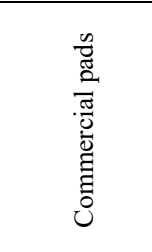 } & $\mathrm{C}$ & 93.23 & 17.10 \\
\hline & C-W & +0.13 & +0.16 \\
\hline & $\mathrm{C}-\mathrm{C}$ & +0.01 & +0.02 \\
\hline & C-C-W & +0.12 & +0.08 \\
\hline & $\mathrm{C}-\mathrm{CYC}$ & +0.01 & +0.12 \\
\hline & C-CYC-W & +0.06 & +0.1 \\
\hline
\end{tabular}

These results indicated that single shallow cryogenic and cyclic-cryogenic treatments improved some physical and mechanical properties of the brake pads. Thus, it would be interesting to conduct further research into how these treatments affect the wear and sliding friction response and the interface strength behavior of the metal surface and the brake pad powders. In addition, due to their viscoelastic characteristics, organic fillers like hazelnut and walnut shell dusts could be used to reduce braking noise and vibration.

\section{CONCLUSIONS}

This study investigated the effects of cryogenic treatment on some physical, mechanical and microstructural responses of brake pads reinforced with hazelnut shell dust as compared to commercial brake pads. The following conclusions can be drawn from the findings:

- Hazelnut shell dust can be used successfully as an organic filler in the production of brake pads.

- The macro and microstructures of the pads did not change significantly after the single and cyclic-cryogenic treatments.

- After the water absorption test, the hardness values of the brake pads were slightly decreased.

- The hardness values of the brake pads increased after the cryogenic and cyclic-cryogenic processes and the highest values were obtained with the B-CYC sample (brake pad with hazelnut dust and cyclic-cryogenic treatment 6 $\mathrm{h} \times 4$ ).

- It can be inferred that the most significant increase in weight amongst all the brake pads occurred in the B-W sample (brake pad with hazelnut dust, immersed in water $24 \mathrm{~h}$ ). Moreover, the C-W pad (commercial brake pad, immersed in water $24 \mathrm{~h})$ absorbed approximately $4 \mathrm{mg}$ of water.

- There were slight variations in the dimensional properties of the brake pads after the immersion in water. The porosity level and inherent nature of hazelnut dust may have caused slightly more water absorption compared to the commercial brake pads. In addition, it is clear from the results that the cryogenic treatments resulted in less water absorption and better dimensional stability for both types of brake pads.

- These results indicate that brake pads produced with hazelnut shell dust could be used commercially after friction-wear tests have been conducted.

\section{ACKNOWLEDGEMENTS}

This study was supported by the Duzce University Scientific Research Project Unit (DÜBAP2015.06.05.313).

\section{REFERENCES}

[1] Aigbodion V., Akadike U., Hassan S., Asuke F. and Agunsoye J., "Development of asbestos-free brake pad using bagasse", Tribology in Industry, 32(1): 12-17, (2010).

[2] Timur M. and Kılıç H., "Marble Waste Using Produced of Automotive Brake Pad of Friction Coefficient Different Pad Brake Pads With Comprasion", Pamukkale University Journal of Engineering Sciences, 19(1): 1014, (2013). 
[3] Qi S., Fu Z., Yun R., Jiang S., Zheng X., Lu Y., Matejka V., Kukutschova J., Peknikova V. and Prikasky M.,"Effects of walnut shells on friction and wear performance of eco-friendly brake friction composites", Proceedings of the Institution of Mechanical Engineers, Part J: Journal of Engineering Tribology, 228(5): 511520, (2014).

[4] Yun R., Filip P., and Lu Y., "Performance and evaluation of eco-friendly brake friction materials", Tribology International, 43(11): 2011-2019, (2010).

[5] Amaren S., Yawas D. and Aku S., "Effect of periwinkles shell particle size on the wear behavior of asbestos free brake pad", Results in Physics, 3: 109-114, (2013).

[6] Idris U., Aigbodion V., Abubakar I. and Nwoye C., "Ecofriendly asbestos free brake-pad: Using banana peels", Journal of King Saud University-Engineering Sciences, 27(2): 185-192, (2015).

[7] Bahari S.A., Isa K.H., Kassim M.A., Mohamed Z. and Othman E. A., "Investigation on hardness and impact resistance of automotive brake pad composed with rice husk dust", in 2nd AIP Conference Proceedings, 1455(1): 155-161, (2012).

[8] Ikpambese K., Gundu D. and Tuleun L., "Evaluation of palm kernel fibers (PKFs) for production of asbestos-free automotive brake pads", Journal of King Saud University-Engineering Sciences, 28(1): 110-118, (2016).

[9] Xin X., Xu C.G. and Qing L. F., "Friction properties of sisal fibre reinforced resin brake composites", Wear, 262(5-6): 736-741, (2007).
[10] Y. Ma, S. Shen, J. Tong, W. Ye, Y. Yang, and J. Zhou, "Effects of bamboo fibers on friction performance of friction materials", Journal of Thermoplastic Composite Materials, 26(6): 845-859, (2013).

[11] Matějka V., Fu Z., Kukutschová J., Qi S., Jiang S., Zhang X., Yun R., Vaculík M., Heliová M. and Lu Y., "Jute fibers and powderized hazelnut shells as natural fillers in nonasbestos organic non-metallic friction composites", Materials \& Design, 51: 847-853, (2013).

[12] Dadkar N., Tomar B.S. and Satapathy B.K., "Evaluation of flyash-filled and aramid fibre reinforced hybrid polymer matrix composites (PMC) for friction braking applications", Materials \& Design, 30(10): 4369-4376, (2009).

[13] Mohanty S. and Chugh Y., "Development of fly ash-based automotive brake lining," Tribology International, 40(7): 1217-1224, (2007).

[14] Fu Z., Suo B., Yun R., Lu Y., Wang H., Qi S., Jiang S., Lu Y. and Matejka V., "Development of eco-friendly brake friction composites containing flax fibers", Journal of Reinforced Plastics and Composites, 31(10): 681-689, (2012).

[15] Akıncıoğlu G., Uygur I., Öktem H., Kır D. and Karakaş, H., "Production and investigation of natural additive brake pads of mechanical properties", presented at the $2^{\text {nd }}$ International Iron and Steel Symposium (IISS'15). Turkey, 472-482, (2015). 